Bolm. Zool., Univ. S. Paulo

3: 1-6, 1978

\title{
ON A NEW SPECIES OF BOSELLIA
}

\author{
Eveline du Bois-Reymond Marcus \\ Departamento de Zoologia \\ Universidade de São Paulo, Brasil \\ Caixa Postal 6994, São Paulo, Brasil
}

\begin{abstract}
One specimen in serial sections with a colour slide of the living animal, from the Red Sea, belongs to the Bosellia mimetica group with small round eyes and ingluvies. It is distinguished from $B$. mimetice by long, pink and white rhinophores. I call it Bosellin cohellia, n. sp. The first specimens of Bosellia mimetice where found in Brazil, Bahia. One juvenile specimen was obtained in the Indian Ocean at Durban.
\end{abstract}

\section{INTRODUCTION}

From Dr. Thomas Everett Thompson I received a photograph and a series of sections of a species of Bosellia from Halimeda with the indication "Red Sea or Mediterranean" Comparison with $B$. (m.) mimetica Trinchese, 1891, from the Mediterranean and from the Western Atlantic showed it to differ from both by much longer and colourful rhinophores. The inner organs are similar. I thank Dr. Thompson for entrusting me with the specimen, as Bosellia is my favorite genus.

To Lic. Yara P. Leite, Salvador, Bahia, I thank for the first specimens of Bosellia from Brazil, especially collected for me on Halimeda at Salvador, Bahia. They belong to Bosellia mimetica (Marcus, 1970). To Dr. Walter People, Durban, S. Africa, I owe a juvenile specimen of a Bosellia Dr. Luise Schmekel, Münster, sent me some of her Bosellia mimetica from Banyuls. 


\section{BOSELLIA COHELLIA, SPECIES NOVA}

\section{MATERIAL}

One colour photograph of the living animal, probably in natural size: $17 \mathrm{~mm}$ long and $14 \mathrm{~mm}$ wide, with 3.0 to $3.5 \mathrm{~mm}$ long rhinophores, and a series of 34 slides with 20 slightly slanting sections, $0.014 \mathrm{~mm}$ thick, on each.

\section{LOCALITY}

Red Sea, or Mediterranean, April 1973, on Halimeda.

\section{DESCRIPTION}

The living animal is dark brownish green like the Halimeda on which it is sitting. Around its border there are small, irtegular, white specks, and farther inward a band of irregular yellowish specks. The rhinophores are rolled in. They have pinkish tips and two broad chalk white bands, the three interrupted by two stripes of the green ground colour. At rest the animal is roundish (Fig. 1).

The dorsal vessels are numerous, about nine veins entering the renopericardiac prominence. The peripheral branches are bifurcate. Farther entally they often anastomose. On the dorsal side there is a distinct furrow between head and neck and the margin of the body.

Preservation and staining of the oblique sections are not quite satisfactory, so that I have to limit my description to the gross anatomy. There are no traces of pigment.

The length of the dissected animal comes to about $9.5 \mathrm{~mm}$, it is $7 \mathrm{~mm}$ broad, and $1.2 \mathrm{~mm}$ high at the renopericardiac prominence. The pigment cups of the eyes measure $0.045 \mathrm{~mm}$ in length and $0.04 \mathrm{~mm}$ in diameter in the sections. The male pore

Figure 1 - Dorsal aspect of living animal from colour slide.

Figure 2 - Diagram of digestive tract.

Figure 3 - Diagram of reproductive organs.

a - ampulla; $b$ - female aperture; $c$ - ingluvial pouches; ci - cerebral ganglia; $d$ - ducts to digestive gland; $\mathrm{e}$ - efferent duct; $\mathbf{f}$ - follicle; $\mathrm{g}$ - buccal glands; $\mathrm{h}$ - hermaphrodite duct; $i$ - ingluvies; $j$ - intestine; $\mathbf{k}$ - female gland mass; 1 - albumen glands; $m$ mouth; $n$ - nephroduct; o - oesophagus; $\mathrm{p}$ - penis; $\mathrm{q}$ - prostatic glands; $\mathrm{r}$ - anus; $\mathrm{s}$ stylet; $t$ - oesophageal pouch; $u$ - pedal ganglia; $v$ - oviduct; $w$ - gametolytic vesicle; $x$ - radula; y - pharynx; z - visceral loop.

Figure 4 - Sketch of stained and clarified specimen of Bosellia mimetica $2 \mathrm{~mm}$ long, from Brazil.

Figure 5 - Sketch of juvenile Bosellia from Durban, South Africa. 


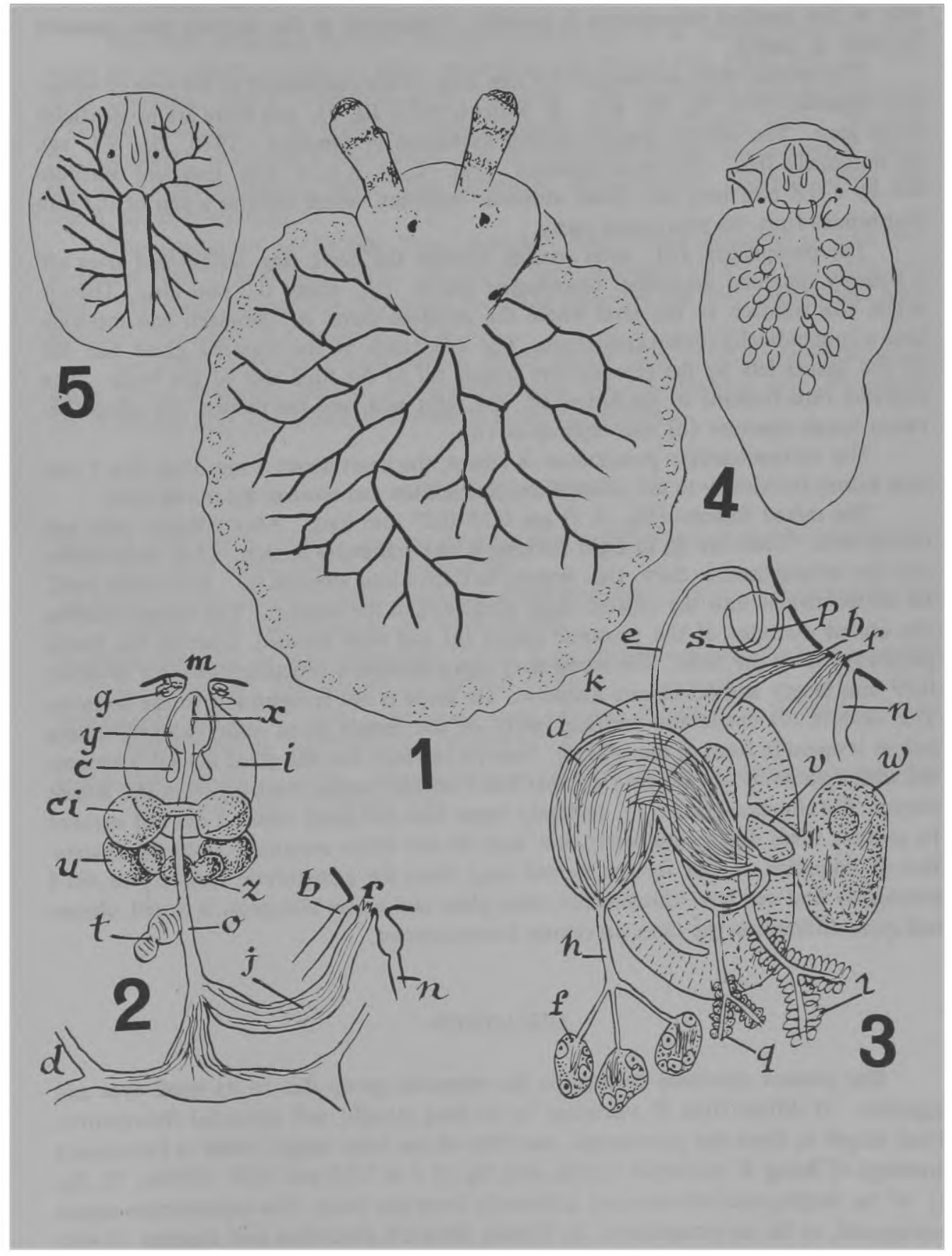


lies under and behind the right rhinophore, the female aperture, $0.3 \mathrm{~mm}$ farther back, immediately in front of the anal opening and the nephropore (Figs. 2,3). The inner side of the inrolled rhinophores is smooth. Contracted in the sections they measure $0.8 \mathrm{~mm}$ in length.

The radular teeth are about $0.04 \mathrm{~mm}$ long. They correspond to the type of mimetica (Marcus, 1970, fig. 96; d.B. R. Marcus, 1973, fig. 7), but there are no denticles to be seen. The salivary glands, so well developed in mimetica (1970, fig, 93, sa), are extremely thin. The small pharynx (Fig. 2, $x$ ) is $0.25 \mathrm{~mm}$ long and surrounded by a $0.8 \mathrm{~mm}$ long and broad muscular ingluvies, which receives a pair of $0.3 \mathrm{~mm}$ long lumina from the pharyngeal cavity.

The oesophagus ( 0 ), after passing through the nerve ring, widens and gives off a strongly muscular dependent oesophageal pouch (t), about $0.2 \mathrm{~mm}$ long. Then it enters the stomach at the level where the intestine leaves it. Stomach and intestine have a longitudinally folded epithelium. The diverticula of the digestive gland (d) fill all the spaces left by the reproductive organs till to the hind end of the body. The intestine runs forward to the furrow on the right side, and the rectum (r) opens between female aperture (b) and nephropore (n).

The renopericardiac prominence is salient, the heart about $1 \mathrm{~mm}$ long, the $3 \mathrm{~mm}$ long kidney lies chiefly to the sides of the pericardium and receives the dorsal veins.

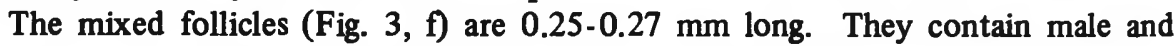
female cells. There are up to eight follicles in one transverse section. Their ducts unite, and the hermaphrodite duct (h) widens to form a long ampulla (a) bent upon itself. Its outlet divides into the ciliated male duct (e) and the oviduct. The former receives the united ductules of the prostatic glands $(\mathrm{g})$ and runs forward, entering the penial papilla (p) from the front. The sperm duct opens through a cuticular stylet (s) of about $0.09 \mathrm{~mm}$ length and $0.012 \mathrm{~mm}$ diameter. Its shape is not recognizable in the sections. The oviduct (v) enters the winding cavity of the female gland mass, (k) and widens before it opens in front of the anus (r). Near its entrance into the gland mass it is connected with a gametolytic vesicle $(w)$, that has a second, vaginal duct (v) from the female atrium. The albumen glands (1) evidently open into the gland mass. I did not succeed to analyze these ducts completely, but they do not differ essentially from the description of mimetica, except for the second duct from the gametolytic vesicle. Nor did I succeed to find out how insemination takes place and where allosperm is stored, characters quite different in the three previously known species.

\section{DISCUSSION}

The present specimen belongs to the mimetica group due to its small eyes and ingluvies. It differs from $B$. mimetica by its long straight and colourful rhinophores. Their length is, from the photograph, one fifth of the body length, while in Portmann's drawings of living $B$. mimetica (1958: 406, fig. 1 ) it is $1 / 15$ and $1 / 20$ (1958a: 75 , fig. 1) of the length, and not coloured differently from the body. The reproductive organs correspond, as far as recognizable, to Renate Becker's descrition and diagram (1960, fig. 1). 


\section{ADDITIONAL NOTES}

The chief difference between Bosellia mimetica and $B$. $m$. curasoae was the difference of the stylets, straight in $B$. m. mimetica (see Pruvot-Fol, 1954: 180, fig. $70 \mathrm{c}$, from Trinchese, 1891), curved in $B$. $m$. curasoae. The specimens from Banyuls have a curved stylet like $B$. $m$. curasoae, quite different from Trinchese's figure. Herewith the subspecific character is invalidated, and the Western Atlantic animals are $B$. mimetica as the Mediterranean ones. The secondary sperm vesicles (Becker, 1960: 200, figs. 5,6 ) were not seen.

The specimens of Bosellia from Salvador, Bahia, were collected on Halimeda at lowest tides in September 1975. Preserved, they measured $2.2 \times 1.3$ and $2.0 \times 0.95$ $\mathrm{mm}$. The short rhinophores, the small eyes, the ingluvies and the curved stylet agree with the characters of $B$. mimetica (Fig. 4).

The juvenile specimen from Durban, South Africa (Fig. 5) from Halimeda among many Elysia halimedae Macnae, was sketched alive, but unfortunately was lost. However, it was the first representative of Bosellia in the Indian Ocean.

\section{LITERATURE CITED}

BECKER, RENATE 1960 Bau und Funktion des Genitalsystems von Bosellia mimetica Trinchese. Rev. Suisse Zool., 68: 194-201, 6 figs.

MARCUS, ERNST and EVELINE du BOIS-REYMOND MARCUS 1970 Opisthobranchs from Curaçao. Stud. Fauna Curaçao, 33: 1-129, 160 figs.

MARCUS, EVELINE du BOIS-REYMOND 1973 On the Genus Bosellia (Mollusca: Gastropod.4; Ascoglossa). Bull. Mar. Sci., 23: 81 1-823, 15 figs.

PORTMANN, ADOLF 1958 Über zwei wenig bekannte Ascoglossa des Mittelmeers (Gastr. Opisthobranchia). Rev. Suisse Zool., 65:405-411, 2 figs.

PORTMANN, ADOLF 1958a Bosellia mimetica Trinchese, Opisthobranche retrouvé en Méditerranée. Vie et Milieu, 9: 74-80, 5 figs. 
